\title{
Water-Power in the United States
}

\section{By Dr. Brysson Cunningham}

II

\section{Grand Coulee Dam}

$\mathrm{T}$ $\mathrm{HE}$ second of the great power projects in the United States to be described is the Columbia Basin Project, Washington. construction of a dam which, when completed, will be the second highest in the world; the formation of an artificial reservoir with an area of 82,000 acres or 128 square miles; the installation of a power plant which will ultimately exceed the eapacity of any other now in existence, and an important irrigation eanal system over adjacent territory.

The Columbia River, rising in the Canadian Rockies and crossing into the State of Washington near its north-east corner, has the greatest run-off but one in the country. It flows for 750 miles through the State into the Pacific Ocean, falling $1,300 \mathrm{ft}$. in its course, and is the largest river in the United States in point of potential power susceptible of economic development. It is obviously, therefore, a very suitable subject for exploitation in the interests of industry and agriculture.

The impounding dam is at the mouth of the Grand Coulee (Fig. 1), a natural basin formed by an earlier diversion of the river channel, probably during the glacial epoch, about 22 miles north of Almira and 92 miles by road west of Spokane. The work of dam construction was commenced in December 1933, and is expected to be completed by the end of the current year. As originally designed, the height of the dam was fixed at $300 \mathrm{ft}$., with a crest length of $3,400 \mathrm{ft}$., which would have served for a power development of 520,000 horsepower. It was the intention thereafter to superimpose a high dam upon this low dam, when funds became available for a combined irrigation and power development scheme. Constructional difficulties, however, arose from slides in the canyon walls above the site, and a consideration of the objectionable bonding of two structures, with the uneconomical accommodation for hydraulic

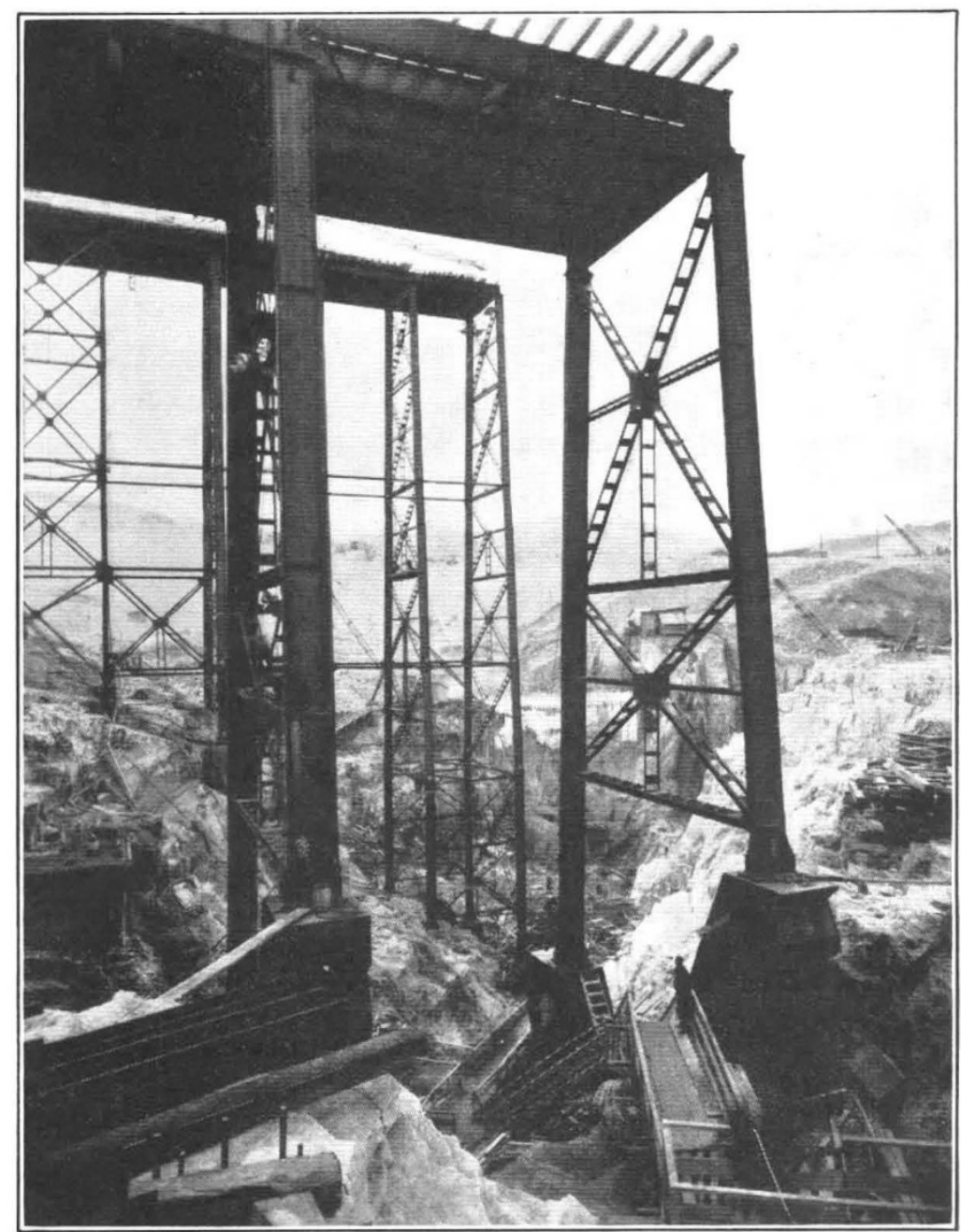

Fig. 1.

View of excavation in progress (December 1936) at Grand Coulee installation. THE CONCRETING OF THE DAM JUST COMMENCED.

machinery to cope with low-head and high-head conditions, led to the substitution, at the outset, of a dam of the concrete straight-gravity type, rising about $550 \mathrm{ft}$. above the lowest point of the foundation bed and capable of raising the riverwater surface-level by $355 \mathrm{ft}$. This dam, 
superimposed on the natural granite, will have a crest length of about $4,200 \mathrm{ft}$., with a $1,650 \mathrm{ft}$. overflow spillway in the river channel portion, affording a flow capacity of a million cusecs. The structure is of enormous size, containing, with the powerhouse and other appurtenant works, no less than $11,250,000$ cubic yards of concrete masonry, weighing more than twenty million tons-roughly, three times the volume and weight of the Boulder Dam.

The reservoir formed by the dam will extend for a distance of 151 miles from the Grand Coulee
The continuous power output will be $1,240,000$ horse-power. There are to be two power houses, one on each side of the dam, containing eighteen 150,000 horse-power vertical hydraulic turbine and eighteen main generating units of 120,000 $\mathrm{kVA}$. capacity each, 60 cycles. There will also be three $7,500 \mathrm{kVA}$. service units. Water will reach the turbines through eighteen penstock culverts, $18 \mathrm{ft}$. in diameter, and the machines will operate under an average head of $335 \mathrm{ft}$. (maximum $360 \mathrm{ft}$. ; minimum $265 \mathrm{ft}$.). It is expected that the plant will be ready to commence partial operation in 1942 .

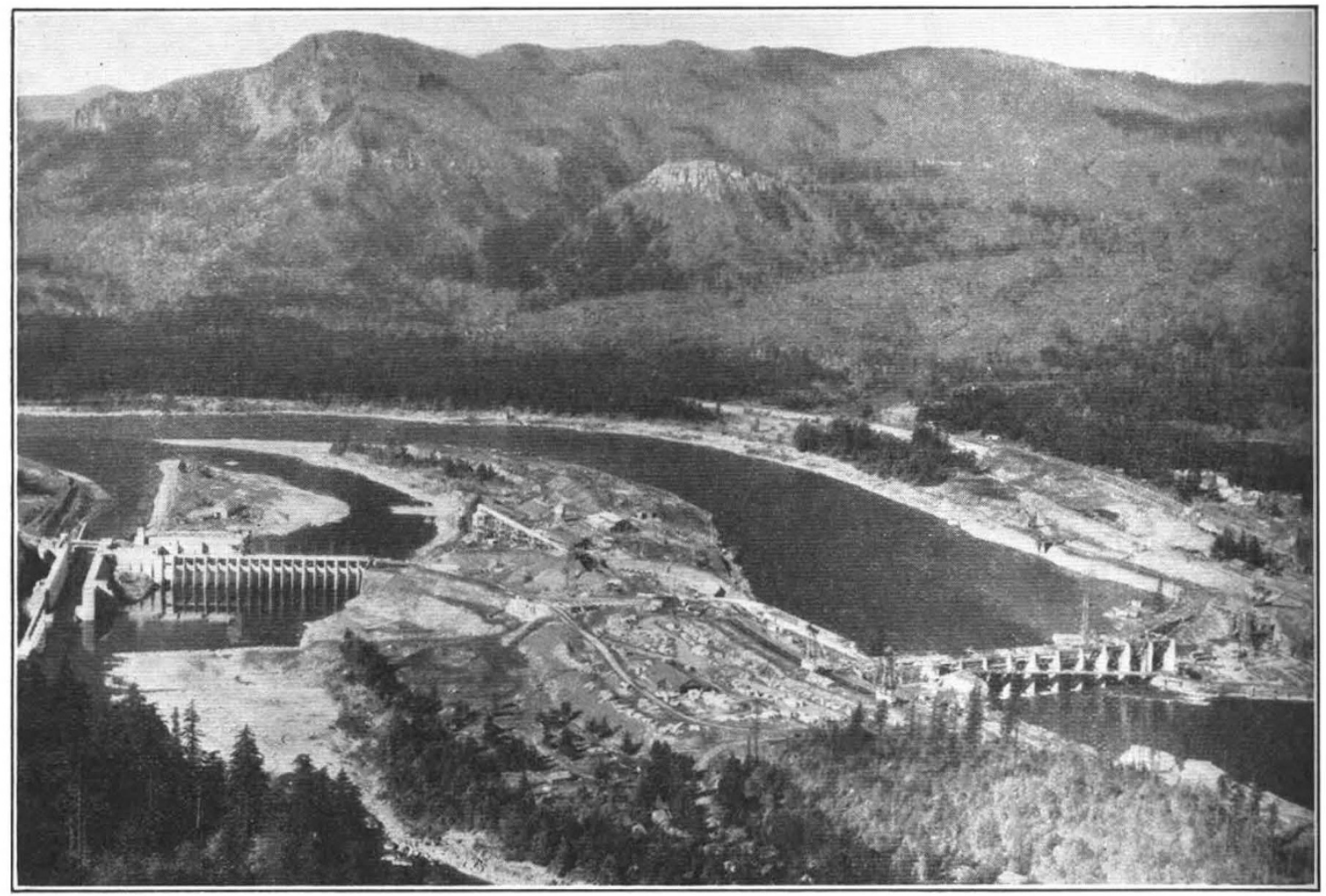

Fig. 2.

General view of the Bonneville installation; upstream side of power house and lock, with SITE OF MAIN DAM.

to the Canadian border, and up the Spokane River for 32 miles. The width averages a little more than $4,000 \mathrm{ft}$. The Columbia River, it may be added, is five times as large as the Colorado River, on which the Boulder Dam is located. The volume of water to be impounded in the Columbia River reservoir is sufficient to supply nearly 2,000 gallons for every inhabitant on the earth. In contrast with the Colorado River, the Columbia River water is practically free from silt.

The installed capacity of the Grand Coulee power plant will be $2,700,000$ horse-power-half as much again as that of the Boulder Dam plant and six times as much as that of Niagara Falls.
The reservoir is to be provided with an installation of twelve pumps, of 1,600 cusecs capacity each, driven by a 65,000 horse-power motor against a normal head of $295 \mathrm{ft}$., discharging through $13 \mathrm{ft}$. diameter outlets, about $700 \mathrm{ft}$. long, in a canal which leads to the reservoir.

The flow of the Columbia River is on an average 109,000 cusecs. The greatest recorded maximum is 492,000 cusecs, but it is believed that a peak of 725,000 cusecs was reached at Grand Coulee during the flood of 1894. The minimum discharge, after completion of the dam and the introduction of regulation, will be about 35,000 cusecs. 
Irrigation is possible over an area of about $1,200,000$ acres in the Columbia Basin, of which 980,000 acres will be by gravity and the remainder by supplemental pumping. The district lies on the east side of the Columbia River, between Soap Lake on the north and Pasco at the extreme southern end, with a maximum width of 60 miles. The land has been declared to be "the best undeveloped irrigation area on the continent".

The estimated ultimate cost of the entire undertaking is $377,000,000$ dollars $(£ 75,400,000)$ of which 179 million dollars is assignable to the dam and power plant and the balance to the irrigation system. The initial development at the Grand Coulee Dam is estimated to cost 60 million dollars.

\section{II}

\section{Bonneville DaM}

The Columbia River furnishes other sites than the foregoing for the economical exploitation of water-power, including Rock Island and Bonneville. The former of these has already been developed by private enterprise ; the development of the latter, Bonneville, is now in hand by the U. S. War Department Corps of Engineers under an authorization of Congress on August 30, 1935. The main features of the Bonneville undertaking are a dam, a power house, a ship lock and fishways. The total cost, inclusive of an initial installation of two (out of ten) power units of 60,000 horsepower each, will amount to 45 million dollars $(£ 9,000,000)$.

The Bonneville site (Fig. 2) is about 143 miles from the coast of the Pacific and the river is tidal for that distance. At this point, the river flows in a westerly direction in two channels, separated by Bradford Island. The dam is being constructed in the north or main, channel, while the power house and navigation lock are located on the south channel. The bedrock under the principal structures is a sedimentary deposit of volcanic ash, largely intermixed with pebbles and rock fragments of all sizes, and is locally known as Eagle Creek formation. There is a mushroomshaped intrusion of andesitic lava of high quality which forms the foundation for the lock and the power house.

The dam is a concrete gravity structure at the base, supporting reinforced concrete piers for eighteen vertical lift steel gates. The gate openings are each $50 \mathrm{ft}$. wide and the piers $10 \mathrm{ft}$. thick, making the length of the dam proper, $1,090 \mathrm{ft}$. The width at the base is $200 \mathrm{ft}$. and the height above lowest foundation, about $170 \mathrm{ft}$. A service roadway is to be carried across the piers, so that the completed dam will have the appearance of a concrete multiple-arch bridge. The dam is designed to pass a flood of $1,600,000$ cusecs-37 per cent in excess of the volume of the flood of 1894 .

The ultimate capacity of the power installation will be ten $43,200 \mathrm{kw}$. units, 3 phase, 60 cycles, and one $4,000 \mathrm{kw}$. station service unit. Each of the main turbines will be of 60,000 horse-power, with a head of $45 \mathrm{ft}$. and a flow of about 2,200 cusecs.

The ship lock is designed to receive oceangoing vessels, so that by deepening the channel below Bonneville (the natural depth of which at low water ranges from $7 \mathrm{ft}$. to $50 \mathrm{ft}$.) such vessels may ascend from Vancouver to The Dalles, about 50 miles above Bonneville. The lock will have clear dimensions of $76 \mathrm{ft}$. in width by $500 \mathrm{ft}$. in length, and a depth of $24 \mathrm{ft}$. over the lower sills. at low water.

The information on which the foregoing article is based has been supplied by the Bureau of Reclamation, Department of the Interior, Washington, so far as the Grand Coulee installation is concerned, and by the Corps of Engineers, U. S. Army, Washington, in relation to the Bonneville project, to both of which bodies, acknowledgments are also made for the photographic illustrations.

\section{Medical Research in 1936}

IN $\mathrm{N}$ addition to the usual summary of the present position of many aspects of medical research, the report of the Medical Research Council* discloses that steps have been taken during the past year to develop the Council's policy of establishing senior clinical posts for whole-time work in research and higher teaching, such as will give a satisfactory career in later life to young men who

* Committee of the Privy Council for Medical Research. Report of the Medical Research Council for the Year 1935-1936. (Cmd. 3378.) Pp. 172. (London: H.M. Stationery Office, 1937.) 38. net. devote themselves to the scientific study of clinical problems. The Council already supports, in whole or in part, three clinical research units in London, at University College Hospital, Guy's Hospital and the National Hospital for Diseases of the Nervous System. Reference is made to the establishment of a department of clinical research at Cambridge, under the regius professor of physic, in which research students are supported by the Elmore Fund, and to Lord Nuffield's gift to the University 